\title{
ВОСПОМИНАНИЯ О ЖИЗНИ И НАУЧНОМ ТВОРЧЕСТВЕ НАТАЛИИ СЕРГЕЕВНЫ СНИГИРЕВСКОЙ
}

\author{
(09.08.1932-06.12.2015) \\ С.М. Снигиревский
}

Санкт-Петербургский государственный университет, Санкт-Петербург, Россия
Эл. почта: s.snigirevskiy@spbu.ru; s.snig@mail.ru

Воспоминания о Наталии Сергеевне Снигиревской (1932-2015), известном отечественном палеоботанике, в течение шестидесяти лет сотруднике Лаборатории палеоботаники Ботанического института им. В.Л. Комарова РАН, о ее жизни и научной деятельности, направлениях исследований и активной жизненной позиции написаны ее сыном и учеником, также палеоботаником, прошедшим с ней некоторые из отрезков научного пути и знающим многое о ее жизни не понаслышке. Можно рассматривать эти воспоминания и как страницу из истории отечественной палеоботаники в Ботаническом институте АН СССР, а ныне - РАН (Санкт-Петербург).

Ключевые слова: Н.С. Снигиревская (персоналия), палеоботаника палеозоя, Neluтьо (лотос), угольные почки, археоптерисовые, Тунгусский взрыв, хвойные мезозоя.

\section{REMINISCENCES ABOUT THE LIFE AND CREATIVE WORK OF NATALIA SERGEYEVNA SNIGIREVSKAYA (09.08.1932-06.12.2015) \\ S.M. Snigirevsky \\ Saint-Petersburg State University, Saint Petersburg, Russia E-mail: s.snigirevskiy@spbu.ru; s.snig@mail.ru}

The present essay about the life, work, and attitudes of Natalia Sergeyevna Snigirevskaya (1932-2015), a renowned Russian paleobotanist who for sixty years was affiliated with the Laboratory of Paleobotany at Komarov Botanical Institute (Leningrad/Saint Petersburg, Russia) is presented by her son and apprentice in the field of paleobotany. His memories discover important aspects, mostly related to Komarov Institute, of the history of paleobotany in Russia

Keywords: N.S. Snigirevskaya, palaebotany, Paleozoic, Nelumbo, coal balls, Archeopteris, Tunguska phenomenon, Mesozoic conifers.

Шестого декабря 2015 г. не стало Наталии Сергеевны Снигиревской, известного палеоботаника, ведущего научного сотрудника лаборатории палеоботаники Ботанического института им. В.Л. Комарова Российской академии наук. Оказавшись ее единственным учеником, считаю своим долгом кратко обрисовать основные вехи ее жизни и научного творчества. К этим воспоминаниям прилагается список основных работ Н.С. Снигиревской (НСС)․․

$* * *$

«Родилась² 9 августа 1932 года в Уфе по дороге родителей (Екатерины Михайловны Снигиревской, в девичестве - Вакуленко, и Сергея Ивановича Снигиревского) из Ленинграда... в Алма-Ата... для проведения зоологических исследований на территории Алма-Атинского государственного заповедника...

Детство (с 3-х до 12,5 лет) вместе с родителями провела в основном в заповедниках (Башкирском и Жигулевском), где получила первые навыки работы с гербарием и наблюдений над животнылми. Принимала участие в марирутах родителей по учету и коллекционированию растений и животных, а также поиску археологических стоянок и остатков ископаемых (преимущественно четвертичных) животных».

${ }^{1}$ Полный список публикаций доступен на сайте журнала «Биосфера» http://21bs.ru.

2 Здесь и далее курсивом привожу отрывки из воспоминаний, написанных Н.С. Снигиревской (далее - НСС); в данном случае - из «Кратких сведений автобиографического характера»; текст прямым шрифтом мои (СМС) добавления.
Волею судеб оказавшись весной 1941 года вне Ленинграда, - на сезонных работах в Жигулевском заповеднике, - наша семья ${ }^{3}$ чудом избежала Блокады. Жизнь в заповеднике была тоже нелегкой, особенно в первую зиму 1941/42 года. Неустроенность, голод, нищета были неумолимы. Юная Наташа кормила всю семью рыбой, которую вылавливала в изрядных количествах в Волге. Сноровка и умение рыбачить сохранились у НСС на многие годы.

«В 1945 г. вернулась вместе с отиом и бабушкой в Ленинград. Поступила в 7 класс 89 школь Петроградского района. Жили мы в прежней квартире на Большой Посадской ул...

У папы постоянно бывали коллеги - зоологи и ботаники, в том числе известные ботаники Б.К. Шиикин, Б.А. Тихомиров, Н.А. Миняев, живший выше этажом и работавиий тогда на кафедре ботаники Ленинградского государственного университета. Так как соседи по квартире были родней Л.А. Куприяновой, известному палинологу и... сотруднику Ботанического института... то с детства я знала многих из знаменитых ученых, с которыми мне пришлось позже встретиться в Ботаническом институте...

В 1950 г. поступила в Ленинградский государственный университет на биолого-почвенный факуль-

$\overline{3}$ Семья состояла из Сергея Ивановича (далее - СИС) и Екатерины Михайловны (далее - ЕМС) Снигиревских, двух дочек - Наташи $(\mathrm{HCC})$ и Кати (ЕСС, родилась перед войной, 30.12.1939 г.), родителей ЕМС - Лидии Николаевны (ЛНВ) и Михаила Викторовича Вакуленко (MBB), а также Анны Петровны Щербаковой, няни ЕMC. 
тет, следуя в значительной мере примеру родителей. Начала работать на двух кафедрах - высшей нервной деятельности (под руководством Л.Л. Васильева, хорошо знавшего дедушку (МВВ)) и зоологии позвоночных - у А.С. Мальчевского. Однако на обеих кафедрах лабораторные исследования были связаны с проведением "острых" опытов... По совету своего двоюродного деда - Николая Николаевича Простосердова (родного брата бабушки (ЛВВ), - известного винодела, профессора, просидевшего много лет на Соловках в связи с какими-то надуманными делами, сосланного затем в Ереван...), занялась растениями, хотя в иколе ботанику не любила. Он посоветовал обратиться за курсовой темой к профессору Армену Леоновичу Тахтаджяну, которого хорошо знал по Еревану и которого иенил очень высоко: "Иди к великому Тахтаджяну”, - сказал он. В то время Тахтаджяна изгнали с поста директора Ботанического института в Ереване за антилысенковские выступления в печати. Он был приглашен на кафедру ботаники в Ленинградский университет, куда был зачислен в 1949 г.

Итак, я обратилась к Тахтаджяну, передавая при вет от деда, что помогло мне сразу найти у него необходимое понимание моей проблемы. Он предложил мне тему курсовой работы по пыльце кувиинковых, что меня вскоре увлекло. Помню, как уже в 1955 г., когда я была еще студенткой, вылла моя первая статья на эту тему. Мой папа особенно был горд $и$ всем показывал ее».

Изучение представителей порядка Кувшинкоцветных (Nymphaeales) стало для НCC «воротами» как в ботанику, так и в палеоботанику. Она осуществила экспедиционный выезд в устье Волги, где собрала обширный материал, послуживший в том числе для написания дипломной работы. На протяжении всей своей долгой научной деятельности, продолжавшейся 60 лет, НСС пронесла трепетное отношение к своей «первой любви в науке» - лотосу. Ее статьи о кувшинкоцветных в основных справочных пособиях: «Жизни растений», «Основах палеонтологии», Большой Советской Энциклопедии, «Ископаемых цветковых СССР», Красной книге РСФСР - до сих пор актуальны и важны. Но не только справочными изданиями ограничивалась НСС в «лотосовой проблеме». В 1992 г. вышла в свет статья о листовом диморфизме и природе семядолей у рода Nelumbo [26], спустя еще четыре года НСС пыталась внести ясность в вопросы о филогенетическом родстве лотосовых. Одна из последних статей $\mathrm{HCC}$ - о распространении рода Nelumbo в меловых флорах - была опубликована примерно за год до ее кончины.

"Интерес к ископаемым растениям возник у меня в связи с новым курсом “палеоботаники”, который читал Армен Леонович. В 1952 г. он познакомил меня с Африканом Николаевичем Криштофовичем - общепризнанным главой школь “советских" палеоботаников, автором учебника "Палеоботаника". Африкан Николаевич посоветовал мне в качестве дипломной работы выполнить монографическое исследование рода Лотос, в том числе изучить его ископаемые находки... Дипломная работа была опубликована в 1964 г. [14]. Помню, как проф. Иван Тихонович Васильченко пришел ко мне с поздравлением по поводу выхода работы в свет и предложил себя в качестве оппонента для ее защиты в качестве кан- дидатской диссертации. Однако в то время (спустя 9 лет после окончания университета в 1955 г.) уменя уже была подготовлена рукопись кандидатской диссертации по так называемым угольным почкам - то есть изучению окаменельх растений в почковидных каменных шарах или конкрециях в каменных углях Донецкого бассейна. Им я посвятила много лет своей жизни...

В 1955 г. я была зачислена в Ботанический институт им. В.Л. Комарова АН СССР (фото 1) - сначала в должности младшего, потом старшего лаборанта. В основном помогала Армену Леоновичу в процессе подготовки к печати "Учебника палеоботаники" А.Н. Криштофовича (умершего в 1953 г.) и его собственной книги "Выстие растения" (1 том - "От псилофитов до хвойных”), которая вышла в свет в 1956 г. В 1960-1972 г2. работала в должности младшего научного сотрудника. В 1964 г. защчитила кандидатскую диссертаичию [13] по среднекарбоновым растениям из каменных углей Украины (Донецкого бассейна)...»

НСС с энтузиазмом взялась за изучение остатков растений-углеобразователей: не менее важным и гораздо более удостоенным ее внимания объектом явились угольные почки Донецкого бассейна. Изучение угольных почек в 1950-1970-е гг. было очень прогрессивным и широко развитым направлением, особенно в Соединенных Штатах Америки, хотя начало этим исследованиям было положено в 1890-х гг. в Англии. Активное изучение угольных почек (coalballs) началось в 1930-х гг. усилиями Джеймса Шопфа (James M. Schopf) и отчасти Уильяма Дарра (William C. Darrah), а продолжилось уже после Второй мировой войны в основном трудами Генри Эндрюса (Henry N. Andrews) и Уилсона Стюарта (Wilson N. Stewart). НСС первой в СССР стала применять метод изучения угольных почек не только в шлифах, но и при помощи пленочных оттисков (rapid peel-technic).

В архиве НСС хранится обширная переписка с американскими коллегами, посвященная вопросам изучения угольных почек. Особенно тесные контак-

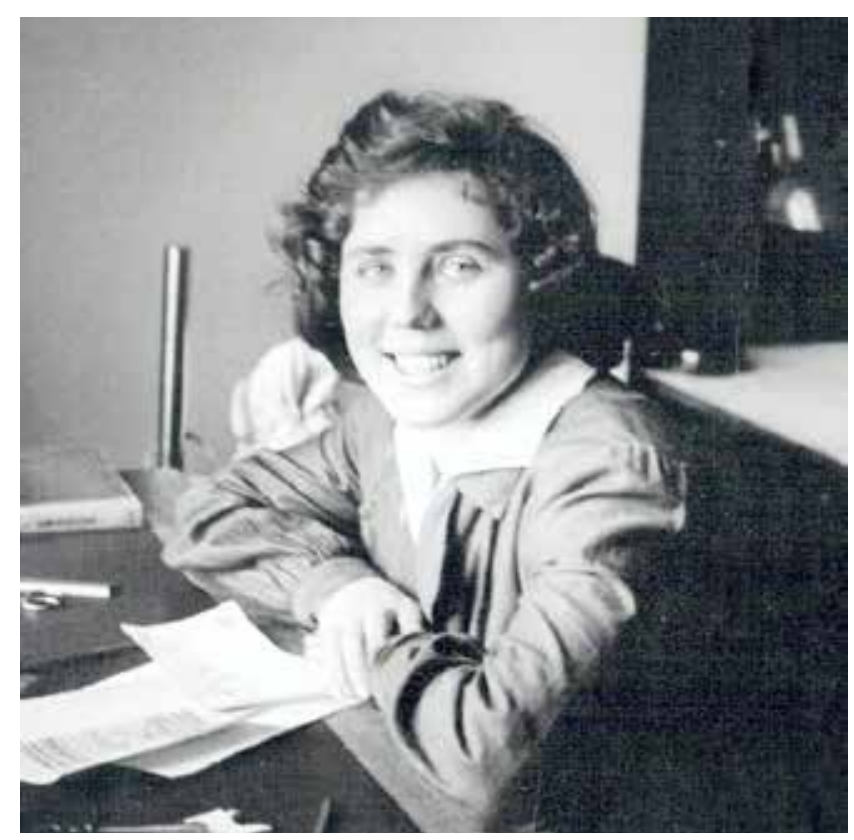

Фото 1. 1956-1957 гг. Н.С. Снигиревская в кабинете Ботанического института РАН 
ты поддерживала она с Г. Эндрюсом, Н. Рэдфортом (N.W. Radforth) и Томом Филлипсом (Tom L. Phillips). Сначала, в 1950-х гг. Эндрюс и Рэдфорт, а позже в 1970-х Эндрюс и Филлипс приезжали в Ленинград, в том числе для совместной работы по изучению угольных почек.

Результаты исследования ископаемых остатков каменноугольных растений изложены в целом ряде публикаций $\mathrm{HCC}[9-12,15,16,21,42,48,54]$. Эти работы выполнены на основании изучения огромного количества материала с применением новейших на то время методик и по праву занимают одно из ведущих мест в мире по глубине проработки и анализа полученных результатов. Важно отметить, что материал собирался в шахтах НСС самостоятельно.

Автору этих строк довелось участвовать в двух экспедициях в Донбасс - в 1974 и в 1976 гг., совместно с геологами Олегом Петровичем Фисуненко и Юрием Ильичом Федченко (оба из Ворошиловграда, ныне Луганска), Ниной Павловной Василюк (из Донецка), а также группой ленинградских ученых - Андреем Витальевичем Лапо (Всероссийский научно-исследовательский геологический институт) и специалистами по третичному периоду Сергеем Глебовичем Жилиным и Еленой Федоровной Кутузкиной (Ботанический институт АН СССР). На местонахождение среднемиоценовых растений «Крынка», которое было также одним из объектов нашей экспедиции 1976 г., приезжал индийский палеоботаник Лакханпал (Rajendra Nath Lakhanpal) (фото 2).

$$
* * *
$$

В 1950-1960-х гг. НСС активно занималась подводным плаванием. На чемпионате Ленинграда по подводному ориентированию (проходил в озерах в районе Поклонной горы - район Озерки) она заняла второе место. «С 1962 являюсь секретарем сек- ичи подводного спорта при Втором морском клубе ДОСААФ и секретарем президиума секиии подводного спорта г. Ленинграда».

Увлечение подводным спортом прочно закрепилось, и в течение многих лет НСС с компанией друзей ежегодно выезжала в Крым для проведения подводных исследований прибрежных участков Черного моря. Исследовательская группа, в которой состояла НСС, производила подводную топосъемку дна Балаклавской бухты, подводных окрестностей Херсонеса; у берегов полуострова Тарханкут обследовались места крушения древнегреческих и римских судов. Со дна были подняты амфоры, монеты, статуэтки, иные предметы материальной культуры далекого прошлого, поступавшие затем в собрание древностей Симферопольского краеведческого музея.

$$
* * *
$$

В конце 1960-х гг. НСС стала уделять много внимания охране ботанических объектов. Но не только охраной живой природы занималась НСС в течение всей своей жизни, но и многократно поднимала вопрос о сохранении геологического наследия - местонахождений ископаемых растений и палеоботанических коллекций. Ею был инициирован важнейший проект, осуществленный к 1994 г., - сбор материалов по всей стране о местонахождениях, нуждающихся в охране. Эти материалы были собраны в сборнике, составителем и редактором которого она была [7].

$$
* * *
$$

Самое начало 1970-х гг. было временем активной работы НСС в партии Московского аэрогеологического треста (начальник партии - Антонина Андрияновна Боручинкина) в качестве палеоботаника. Несколько летних сезонов провели они совместно на берегах Нижней Тунгуски.

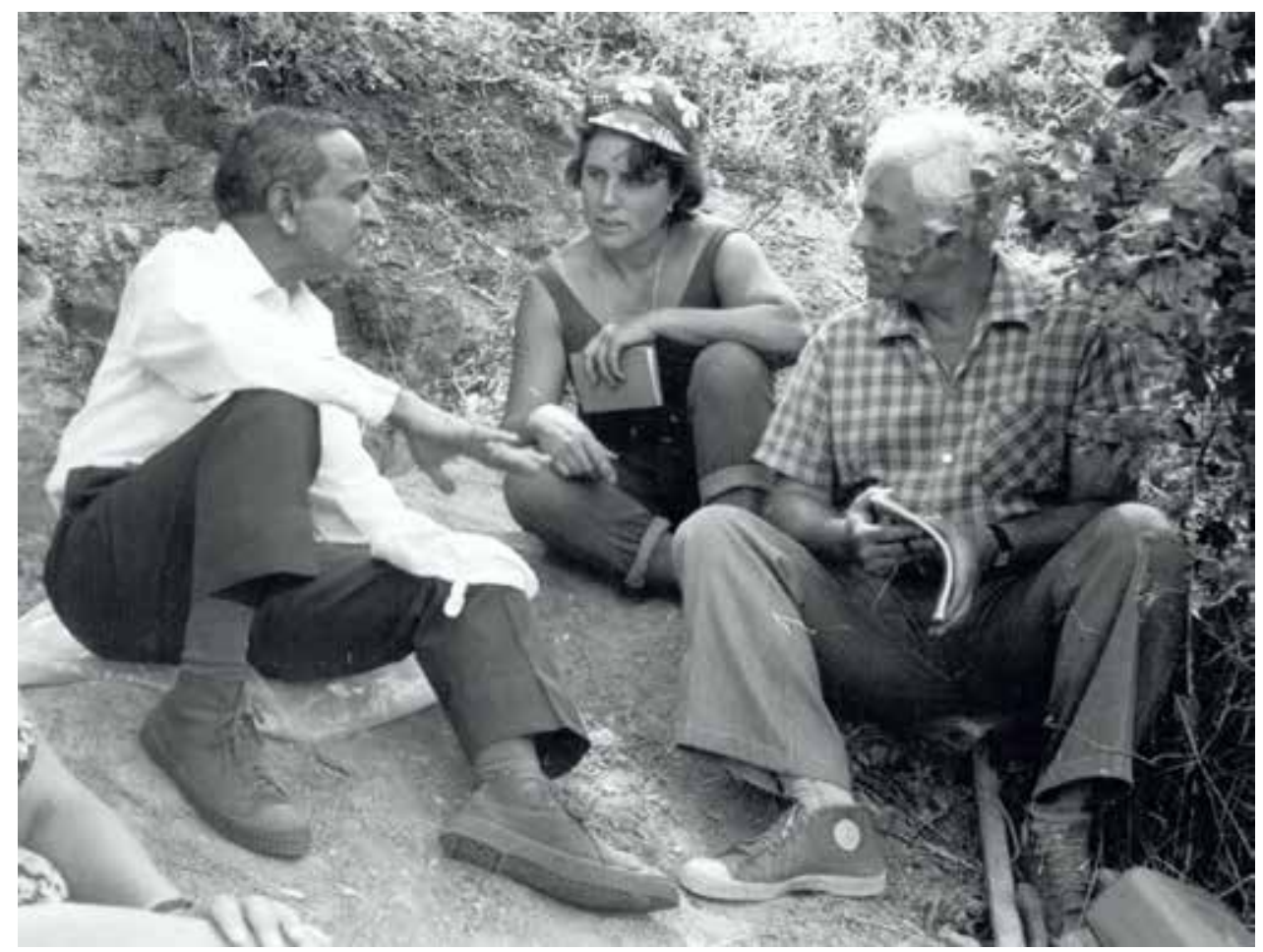

Фото 2. 1976 г.: беседа на разрезе местонахождения третичных ископаемых растений «Крынка». Слева направо: индийский палеоботаник Лакханпал, Н.С. Снигиревская, Ю.В. Тесленко 
Во время таежных экспедиций у НСС сформировалось убеждение в том, что палеоботанические материалы максимально высокого качества могут собрать только специалисты-палеоботаники. Геологи, как бы тщательны они ни были при сборе материалов, никогда не смогут отобрать материал, содержащий максимальное количество признаков ископаемого растения. Это понимание привело позже к осуществлению уникальных сборов стволов девонских археоптерисовых с корневыми системами в Донецком бассейне. А в начале 1970-х, в Восточной Сибири, в районе развития трапповых формаций триасового возраста НСС коллекционировала ${ }^{4}$ уникальные фоссилии, сохранившиеся практически целиком и представляющие, соответственно, вполне естественный род ископаемых растений. Имя новому роду было избрано в честь учителя, «во славу Тахтаджяна» - Takhtajanodoxa. НСС предложила выделять новые порядок и семейство - Takhtajanodoxales Snig. ordo nov. и Takhtajanodoxaceae Snig. fam. nov. Это - не известное ранее новое звено в эволюции плауновидных, которое связывает между собой древовидные лепидодендроновые карбона и современные изоэтовые [18]. Целый ряд сибирских палеоботанических находок позволил расширить спектр изучаемого НСС материала «вверх по геологическому разрезу» - был опубликован также материал по юрским матониевым папоротникам [17].

Мезозойские ископаемые растения (преимущественно триасового возраста) продолжали оставаться в сфере пристального внимания НСС в течение многих последующих лет $[24,40,49]$. В творческом содружестве с Д.В. Громыко, Н.К. Могучевой и Л.А. Фефиловой опубликован целый ряд работ, посвященных в том числе палеоксилотомическому исследованию мезозойских древесин голосеменных, преимущественно хвойных, растений $[8,37,38,41,46,50]$.

$$
* * *
$$

«В 1957 г. я была принята в члены Всесоюзного ботанического общества (ныне - Русское ботаническое общество). С 1983 г. я являюсь председателем Секиии палеоботаники и членом Совета этого обшества. Так как я занималась активно систематикой современных и ископаемых растений, в 1969 г. меня приняли в члены Международной организации таксономистов растений. Поскольку мы не имели возможности переводить деньги за членство, их за меня платил профессор Франс Антони Стафле (Утрехт, Нидерланды) - главный редактор журнала “Таксон" и Международного кодекса ботанической номенклатуры в версии 50-70-х годов. В 1975 г. я была избрана в состав Международной организации палеоботаников, где с 1981 по 1993 г. была членом Исполнительного комитета (итаб-квартира Организаичи была тогда в Лондоне)».

Примерно в 1972 г. НСС приступила к подготовке и организации XII Международного ботанического конгресса (МБК), местом проведения которого был выбран Ленинград, а организацией, ответственной за его проведение, - Ботанический институт АН СССР. Впервые в своей жизни столкнувшись с административной стороной дела, НСС всецело погрузилась в работу по организации Конгресса, отодвинув на

4 Первые находки представителей новой группы были сделаны геологом Л.Л. Исаевой. время на «второй план» не только научную деятельность, но и личную жизнь.

Именно в эти годы к НСС в гости очень часто приходили и приезжали из других городов друзья и коллеги, в основном палеоботаники и геологи. Среди них - крупнейший палеоботаник Сергей Викторович Мейен, занятый в то время организацией 8 Международного конгресса по стратиграфии и геологии карбона (Москва, 8-13 сентября 1975 г.); украинские палеоботаники Юрий Владимирович Дукельский-Тесленко ${ }^{5}$, известный по публикациям как Ю.В. Тесленко; Андрей Константинович Щеголев; Олег Петрович Фисуненко; ленинградские коллеги и друзья - Сергей Глебович Жилин, Галина Васильевна Делле, Валерьян Сергеевич Муромцев, Наталья Дмитриевна Агапова, Елена Федоровна Кутузкина. Приезжали: из недосягаемой тогда Америки Том Филлипс (T. Phillipps) и Генри Эндрюс (H. Andrews), из не менее недосягаемой Англии - Билл Чалонер (William Chaloner).

Оценить объем сделанного НСС невозможно. Итогом подготовительных работ явилось блестящее проведение МБК, о котором в ботаническом мире было сказано немало восторженных слов [45]. НСС по праву являлась первой звездой Конгресса: ученый секретарь с прекрасным английским, уже в те годы признанная как классный специалист в области изучения угольных почек Донбасса, красивая и умная, доброжелательная и отзывчивая, - такой осталась НСС для многих зарубежных коллег, помнящих ее с тех уже давних пор (фото 3). Успех Конгресса обусловил и немалый успех НСС в научной среде. В вышедшей в 1980 г. книге американского палеоботаника Генри Эндрюса (H.N. Andrews) «The fossil hunters: In search of ancient plants» излагается краткая история палеоботаники в США и по отдельности - в странах Старого Света. Тексты сопровождаются фотографиями наиболее известных палеоботаников. На СССР приходится три фотографии - это М.Д. Залесский, А.Н. Криштофович и Н.С. Снигиревская. В 1994 г. НСС была награждена двумя международными дипломами: «Женщина года» (фото 4) и «За международное сотрудничество» по версии Биографического института Соединенных Штатов Америки.

$$
* * *
$$

В конце 1970-х гг. НСС расширяет круг своих палеоботанических интересов. Это было связано, с одной стороны, с подготовкой многотомного издания «Жизнь растений» под руководством А.Л. Тахтаджяна, с другой - с многочисленными полевыми работами в Донбассе и посещением классических местонахождений ископаемых флор девонского возраста Южного Донбасса - Стылы, Раздольного (Каракубы) и ряда других. Впервые описанные И.Ф. Шмальгаузеном в 1894 г., ископаемые остатки растений из верхнедевонских отложений были также впоследствии изучены сначала М.Д. Залесским, а затем и Т.А. Ищенко. В процессе подготовки к продолжительным и тщательным полевым исследованиям (которые были успешно осуществлены в 1980 г.) НСС детально прорабатывала имеющиеся к тому времени данные по археоптерисовым флорам. На

\footnotetext{
5 Юрий Владимирович часто останавливался у НСС дома во время своих ленинградских визитов, Сергей Викторович тоже пару раз гостил у нее.
} 


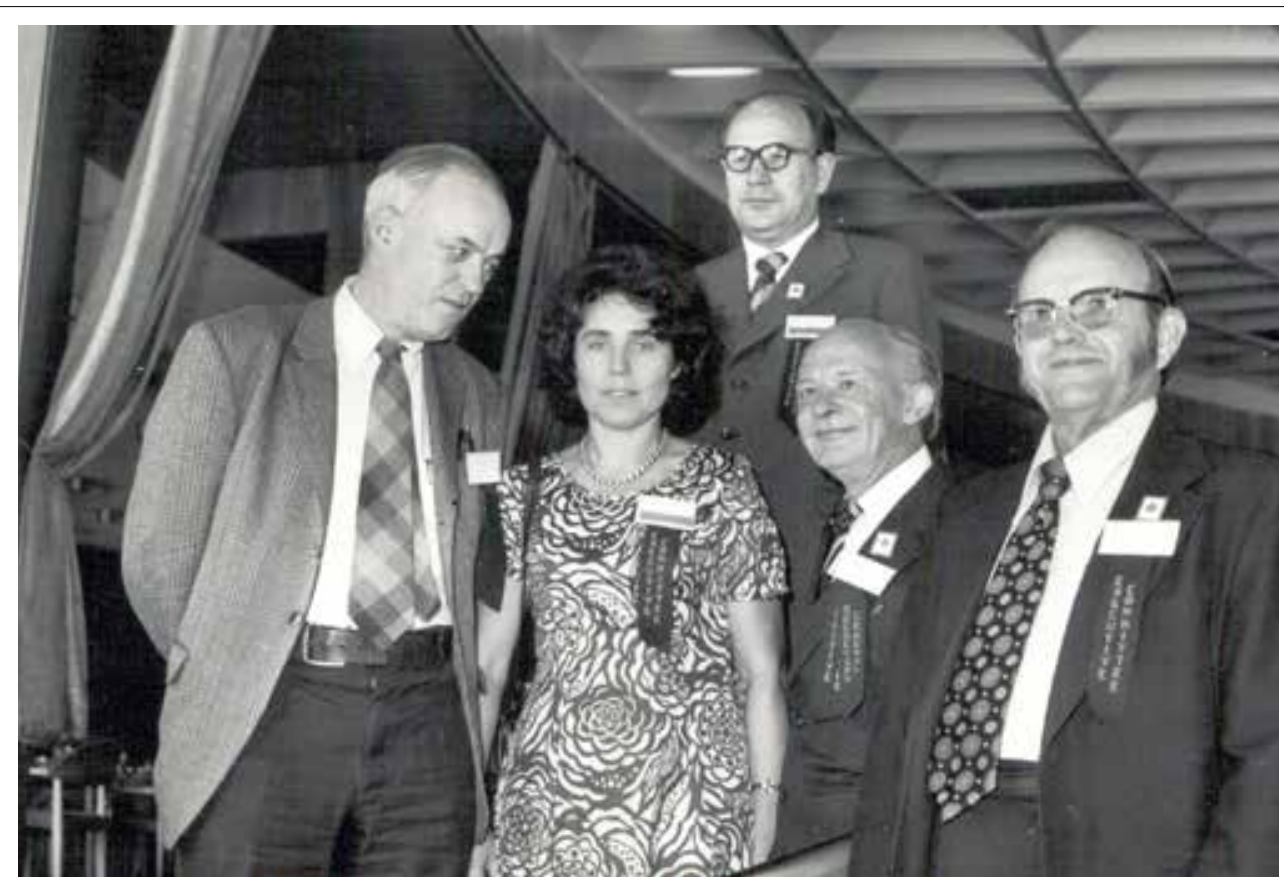

Фото 3. 1975 г.: Международный ботанический конгресс. Слева - Франс Стафлё, рядом с ним - Н.С. Снигиревская

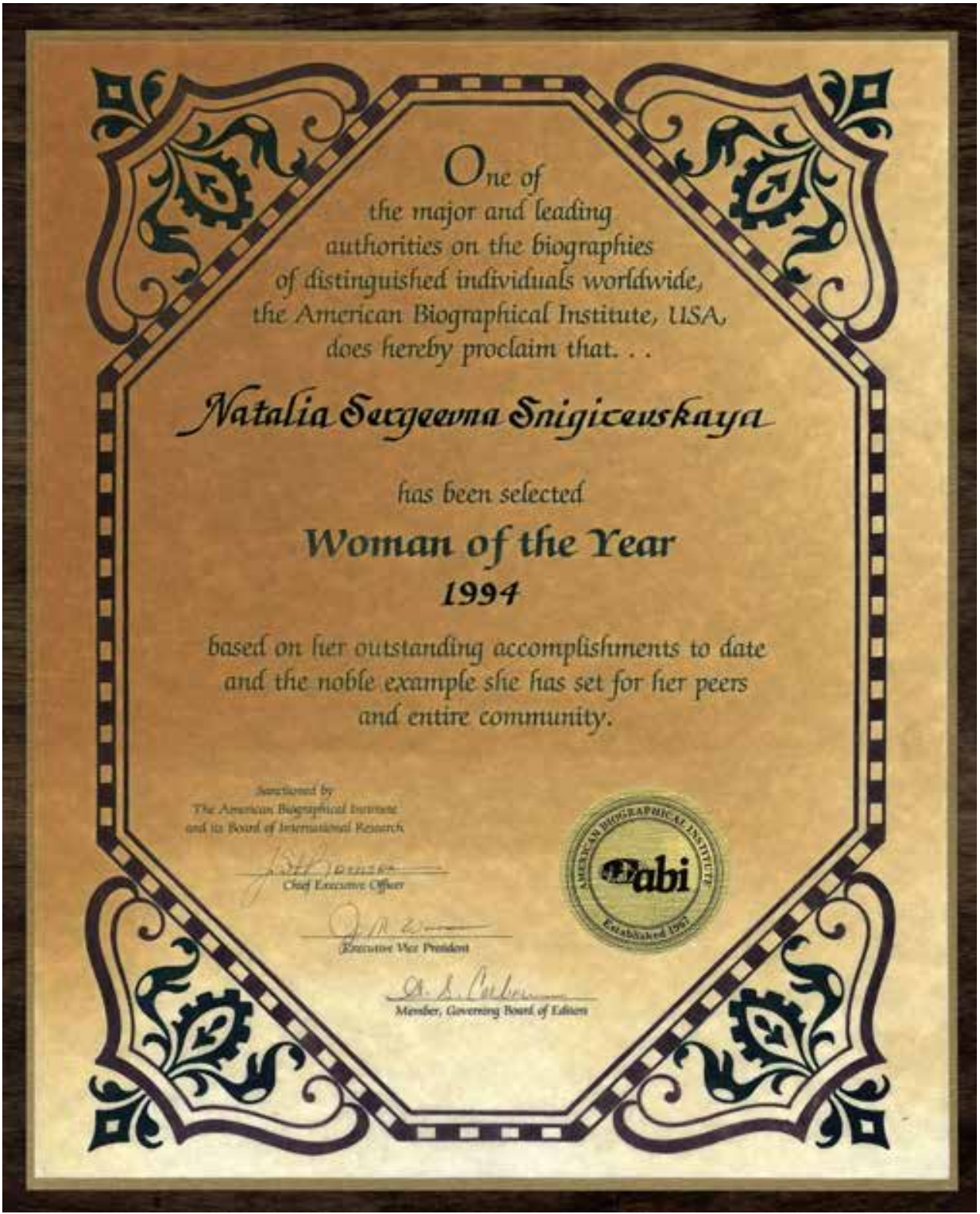

Фото 4. Диплом Американского биографического института: Н.С. Снигиревская избрана «Женщиной года 1994» 
VI делегатском съезде Всесоюзного ботанического общества (ВБО) НСС выступила с докладом «К систематике древнейших папоротников», в котором впервые предложила рассматривать археоптерисовые в качестве самостоятельного класса (Archaeopteridopsida). Обоснование высокого таксономического ранга этой группы привело впоследствии НСС к выделению самостоятельного отдела растительного царства - Archaeopteridophyta [30].

Экспедиция в Южный Донбасс, в Раздольное (бывшее греческое поселение Каракуба) к югу от поселка Комсомольское (при впадении р. Мокрая Волноваха в p. Кальмиус) в 1980 г. была продолжительной и очень успешной. Мне посчастливилось в тринадцатилетнем возрасте участвовать в этой экспедиции в течение без малого трех месяцев. Основной идеей коллекционирования ископаемых остатков растений была попытка препарировать найденные окаменелости непосредственно в обнажении. В особенности это касалось крупномерных стволов позднедевонских древесных растений - археоптерисов. Такой подход позволял избежать фрагментарности собранного материала. Основными инструментами были кувалда и зубило, несколько геологических молотков и деревянные клинья. Расчистки производились планомерно, в тех местах, где из стенки обнажения торчали окаменелые древесины. Ширина, глубина и длина расчисток зависели от размеров сохранившихся фрагментов. В основном это были полтора-два метра вскрыши, около метра шириной и до трех метров в глубину обнажения. Расчистка одного такого ствола занимала примерно полторы-две недели.

Результаты превзошли все ожидания. Были отобраны не только крупные фрагменты стволов калликсилонов (до 2-3 метров длиной), но и корневые системы, сохранившиеся практически целиком. Отбор проб осуществлялся путем детальных зарисовок расчищенных корневых систем, наклеивания этикеток на каждый кусочек, записи в дневнике и фотографирования. По результатам экспедиции в Ленинград было отправлено 83 ящика с тщательно отобранными пробами.

К сожалению, монтаж корневых систем является очень трудоемким процессом, и НСС удалось собрать полностью только один пень, который в настоящее время хранится в Музее Ботанического института РАН (он изображен на титульном листе книги «Местонахождения ископаемых растений, нуждающиеся в охране»). Остальные материалы ждут своего часа.

По результатам изучения девонских флор Донбасса НСС опубликовала целый ряд работ $[19,20,22,23,28$, $32,47,51]$, предложила новую реконструкцию растения - археоптериса (Archaeopteris). Опубликованные ранее и ставшие на долгие годы «классическими» реконструкции Чарльза Бека (Ch. Beck) не учитывали строение нижних частей растения, и стволы оканчивались у поверхности почвы, не показывая характер корневых систем этих растений. Новые находки в Южном Донбассе позволили расширить наши представления об этих удивительных растениях.

$$
* * *
$$

Совместно с НСС мы изучали ископаемые остатки растений девонского [43] и раннекаменноугольного возраста из отложений Северо-Запада России, собранные мною во время моих студенческих пра- ктик, коротких экспедиционных выездов, а в период 1994-2002 гг. - с учениками палеонтологического кружка Клуба юных геологов им. акад. В.А. Обручева Санкт-Петербургского городского Дворца творчества юных. В результате за эти годы постепенно накопился материал, достаточный для его изучения. Кроме того, совместная экспедиция на р. Мсту в окрестности Боровичей в 1992 г. дала новый интересный материал.

Традиционно считалось, что Северо-Запад России не богат остатками ископаемых растений. И действительно, на первый взгляд породы девона и нижнего карбона практически не содержат фитофоссилий. Однако при длительном и детальном изучении геологических разрезов оказывается, что растительные остатки здесь все же существуют, хотя в ограниченных количествах. Наиболее широко представлены они в Новгородской области в разрезах по берегам реки Мсты. Описанные М.Д. Залесским в 1905, а затем в 1946 годах, они долгое время оставались не изученными. Нашими совместными усилиями были собраны первые коллекции «после-Залесского» времени. Уже позже эту ископаемую флору стала изучать в творческом сотрудничестве с нами О.А. Орлова из МГУ, а еще позже - Ю.В. Мосейчик и И.А. Игнатьев (Геологический институт РАН). Одни из первых публикаций по нижнекаменноугольной флоре Боровичей основаны как раз на материалах совместной экспедиции в Боровичи [44 и др.].

Немалый материал по древесинам археоптерисовых из песчано-глинистых отложений ГДП также собирался «по крупицам» в течение многих лет. Оказалось, что остатки древесин растений, первыми на Земле сформировавшими новые на тот момент (поздний девон) лесные сообщества, встречаются по краям Балтийского щита, который, видимо, был покрыт в позднем девоне археоптерисовыми лесами. Совместное изучение имеющихся материалов позволило очертить круг новых местонахождений археоптерисовых на Северо-Западе России [53].

$$
* * *
$$

1990-е гг. - время активной работы НСС над еще более древними ископаемыми остатками растений «додевонскими». Хорошо зная чехословацкого палеоботаника Иржи Обргела (Jiří Obrhel) и его работы по предположительно высшим растениям из древнейших толщ Европы, НСС начала изучение этого вопроса с анализа проблематичных девонских остатков Orestovia [27], обладающих целым рядом признаков, позволяющих рассматривать эти растения как высшие (в том числе наличие образований, похожих на устьица). Правильнее даже будет, наверное, говорить о том, что к вопросу об орестовиях НСС пришла через аналитическое осмысление материалов по среднедевонским плауновидным Barsassia, у которых ею совместно с Л.А. Богдановой были установлены устьица и следы ксилемы [36].

Работа, опубликованная в Palaeontographica и посвященная изучению орестовий, позволила составить реконструкцию этих растений, основываясь на их сходстве с современными марсилеевыми [52].

Экспедиция в Казахстан и сборы органических остатков из силурийских и ордовикских отложений привели НСС к целому ряду открытий уникальных объектов, представляющих первые ступени эволю- 
ции наземных биоценозов. К сожалению, указанные находки не получили должного широкого освещения в работах НСС $[29,39]$. Итоговую работу по древнейшим фитофоссилиям НСС опубликовать не успела...

$\mathrm{B}$ процессе изучения древнейших фоссилий НСС много общалась с известным британским палеоботаником Дайаной Эдвардс (Diana Edwards, Университет г. Кардифф (Уэльс)), руководящей в течение многих лет международной группой исследователей уникального местонахождения древнедевонских растений из «райниевых чертов» в Шотландии. Уникальность местонахождения заключается в том, что в подобных халцедону кремнистых полупрозрачных породах сохранился биоценоз древнего «болота», переполненный остатками растений (за многие годы изучения этих материалов обнаружены спорофиты и гаметофиты древних растений; изучены фаунистические находки; восстановлены экологические группировки и мн. др.). У НСС было несколько образцов из этого уникального местонахождения, собранных А.Л. Тахтаджяном во время его поездки в Англию. Попутно изучая эти образцы, НСС обнаружила в препаратах новое ископаемое членистоногое, описание которого так и не было опубликовано. Не менее продуктивный обмен мнениями по биоценозам Райни происходил у НСС с супругами Тейлорами (Tom Taylor и Edith Taylor): обмен оттисками, постоянная переписка с этими тремя исследователями привели НСС к постановке вопроса о симбиозе растений и грибов в геологическом прошлом. Материал был «под рукой», а в Ботаническом институте РАН активно работал над этим вопросом известный миколог Игорь Васильевич Каратыгин.

$$
* * *
$$

В рамках научной темы по Программе РАН «Эволюция биосферы» НСС в творческом содружестве с И.В. Каратыгиным, К.Н. Демченко, Р.Н. Беляковой и С.В. Викулиным провели целый ряд исследований микроскопических фоссилий, среди которых были обнаружены остатки мицелия грибов, лишайники, цианобактерии и другие уникальные объекты, которым ранее придавалось малое значение, или они вообще оставались без внимания специалистов. Необходимо отметить, что изучение микрофоссилий со временем приобретает все больший размах в первую очередь благодаря развитию и производству увеличительной техники, в том числе такой, как сканирующие электронные микроскопы.

Именно здесь хотелось бы отметить организаторские способности НСС, направленные на техническое обеспечение БИНа. В те времена, когда директором БИНа был А.Л. Тахтаджян, инициативная группа, в которую входила НСС, добилась открытия в институте электронно-микроскопической лаборатории и приобретения наиболее современного на тот период сканирующего электронного микроскопа (СЭМ). Благодаря его наличию стало возможным изучать клеточные структуры современных и ископаемых растений при огромных увеличениях. НСС была, наверное, первым отечественным специалистом, который стал применять СЭМ при изучении ископаемых растений, в первую очередь окаменелых древесин.

Имея огромный опыт в применении СЭМ для решения вопросов анатомического строения растений,
НСС расширила использование электронной микроскопии на изучение ископаемых грибов. Оказалось, что структуры, на которые раньше специалисты не обращали особого внимания, представляли собой гифы грибов, фрагменты мицелия, бактерии и т. д. Проникновение в микромир, ранее недоступный человеческому глазу, привело к удивительно интересным открытиям, которые были описаны в целом ряде работ научного коллектива под руководством НСС и И.В. Каратыгина [1-6].

$$
* * *
$$

Очень большое внимание, правда, к сожалению, не оформленное в виде публикаций, придавала НСС микропалеоботаническому изучению вулканических трубок. Еще в 1980-е гг. сотрудник ЦНИГРИ С.М. Саблуков передал на определение С.В. Мейену и Н.С. Снигиревской целый ряд образцов из жерловых фаций кимберлитовых трубок с Зимнего берега Белого моря. С.В. Мейен определил их как фрагменты крупноствольных пикноксильных растений, очевидно, калликсилонов. Применение сканирующего электронного микроскопа позволило НСС подтвердить это предположение. Несомненный первый успех в датировках времени кимберлитового вулканизма расширил профессиональные контакты «кимберлитчиков» с палеоботаниками, и к концу 1980-х гг. определениями такого рода материалов занималась не только НСС (С.В. Мейен рано ушел из жизни, в 1987 г.), но и А.Л. Юрина.

Если не считать многочисленные определения ископаемых остатков растений, вошедшие в работы специалистов по «алмазной тематике», у НСС есть лишь одна публикация [34], обобщающая все исследования материалов из кимберлитовых трубок и объясняющая важность такого изучения.

Логически, именно как следствие длительного плодотворного сотрудничества со специалистами в области кимберлитового вулканизма, в сознании НСС постепенно стала выкристаллизовываться идея об ошибочности взглядов на природу феномена, известного как «Тунгусский метеорит» ${ }^{6}$.

Хорошо помню, как в конце 1980 г. НСС увлеченно рассказывала о том, что в США произошло извержение вулкана Сент-Хеленс ${ }^{7}$, сопровождавшееся так называемым «направленным взрывом». Вывалы леса в районе этого вулкана после извержения оказались удивительно схожими с теми, что наблюдались в районе тунгусского взрыва. В произошедшее трудно было поверить, но по многим параметрам получалось, что «Тунгусский метеорит»- это не метеорит...

Выше я писал, что именно на 1980-е гг. приходится начало работ НСС с остатками растений из кимберлитовых трубок. Не одними определениями занималась она, но и совместно с С.М. Саблуковым и С.В. Мейеном, а в последние годы - с Г.Т. Скубловым,

\footnotetext{
6 Здесь и далее понятие «Тунгусский метеорит» поставлено в кавычки. Из нижеследующего текста будет понятно, что в действительности событие 1908 г., скорее всего, не было метеоритом.

${ }^{7}$ Необходимо отметить, что НСС (вслед за ошибочным переводом в средствах массовой информации) использовала неверное название вулкана - святой Елены. На самом деле Сент-Хеленс назван в честь британского дипломата лорда Сент-Хеленса, друга исследователя Джорджа Ванкувера, который проводил топографические работы в этом районе в конце XVIII в. (https://ru.wikipedia.org/wiki/СентХеленс).
} 
они пытались осмыслить, каким образом попали органические остатки (древесины, листовые органы, порою моллюски и другие животные) в кимберлиты - магматические породы, сформировавшиеся в условиях огромных температур и давлений в процессе кратковременного взрыва. Объяснение могло быть только одним: взрыв должен был произойти в том месте, где произрастали эти растения и где в водоемах (скорее всего, озерного типа) жили эти животные. Мгновенный взрыв приводил к захвату магматическим веществом фрагментов органических остатков - как ксенолитов из окружающих горных пород при движении расплава сквозь их толщу.

Со временем сопоставлявшиеся и накапливавшиеся факты привели к формированию логичной картины механизма тунгусского взрыва. «Тунгусский метеорит», по НСС, - это, скорее всего, взрыв, подобный вулканическому, сопровождавшийся выбросом газов из недр Земли и взрывом этих газов в нижних слоях атмосферы. Взрывная волна привела к массовому вывалу леса. Многолетние поиски хондритов в этом районе не могли привести к успеху, так как их там не могло быть «по определению».

Одна из последних статей НСС - «Вулканическая природа Тунгусского взрыва 1908 года и его значение для понимания истории растительных ландшафтов Средней Сибири России» [35].

$$
* * *
$$

И все же НСС в первую очередь была ботаником. Огромное значение она придавала терминологии, номенклатуре, а также таксономии. Она буквально «взрывалась», когда слышала, например, использование термина «колосок» (или «спороносный колосок») в применении к спороносным органам древних растений (например, риниофитов), и, тем более, термина «шишка» в применении к репродуктивным структурам плауновидных - стробилам. Лепидодендроны не имели хорошо развитых механических тканей, соответственно, обладали «стеблями», а не стволами. Этот список терминов можно продолжать.
В конце 2000-х НСС несколько раз выступала против неоправданного «упрощения» номенклатурных вопросов, в действительности приводящих к существенным усложнениям. В первую очередь это касалось закрепленных в новых редакциях Международных кодексов ботанической номенклатуры трактовок тех или иных терминов или понятий. Особенной критике НСС подверглась концепция «морфотаксона», утвержденная на Сент-Луисском конгрессе и поддержанная Венским конгрессом в 2006 г. [31].

$$
* * *
$$

Применение метода пленочных оттисков, подготовка препаратов для исследования в сканирующем электронном микроскопе требовали, безусловно, высочайшей технической квалификации исполнителя. Вопросам методики приготовления препаратов посвящено множество работ известных отечественных и зарубежных ученых, которые самостоятельно пытались усовершенствовать уже существующие и создавали новые методики. НСС не оставалась в стороне от этого: ускоренный метод получения пленочных оттисков был изобретен ею еще в процессе написания кандидатской диссертации, в середине 1950-х гг. Об угольных почках и методах их изучения НСС публиковала научно-популярные статьи в журнале «Природа», а также несколько раз возвращалась к объяснению методических приемов исследования угольных почек Донбасса в среде специалистов.

Выше уже упоминалось, что НСС, наверное, была первым отечественным палеоботаником, который применил для изучения ископаемых остатков растений сканирующий электронный микроскоп. Однако для успешного проведения исследования фоссилий на технике еще старого образца необходимо было подготовить объекты определенным образом: прикрепить на немагнитные «столики», «напылить» золотом. НСС сама разработала методику подготовки таких препаратов. При этом она активно делилась с коллегами и людьми, интересующимися палеонтологией, новыми методами исследования ископаемых

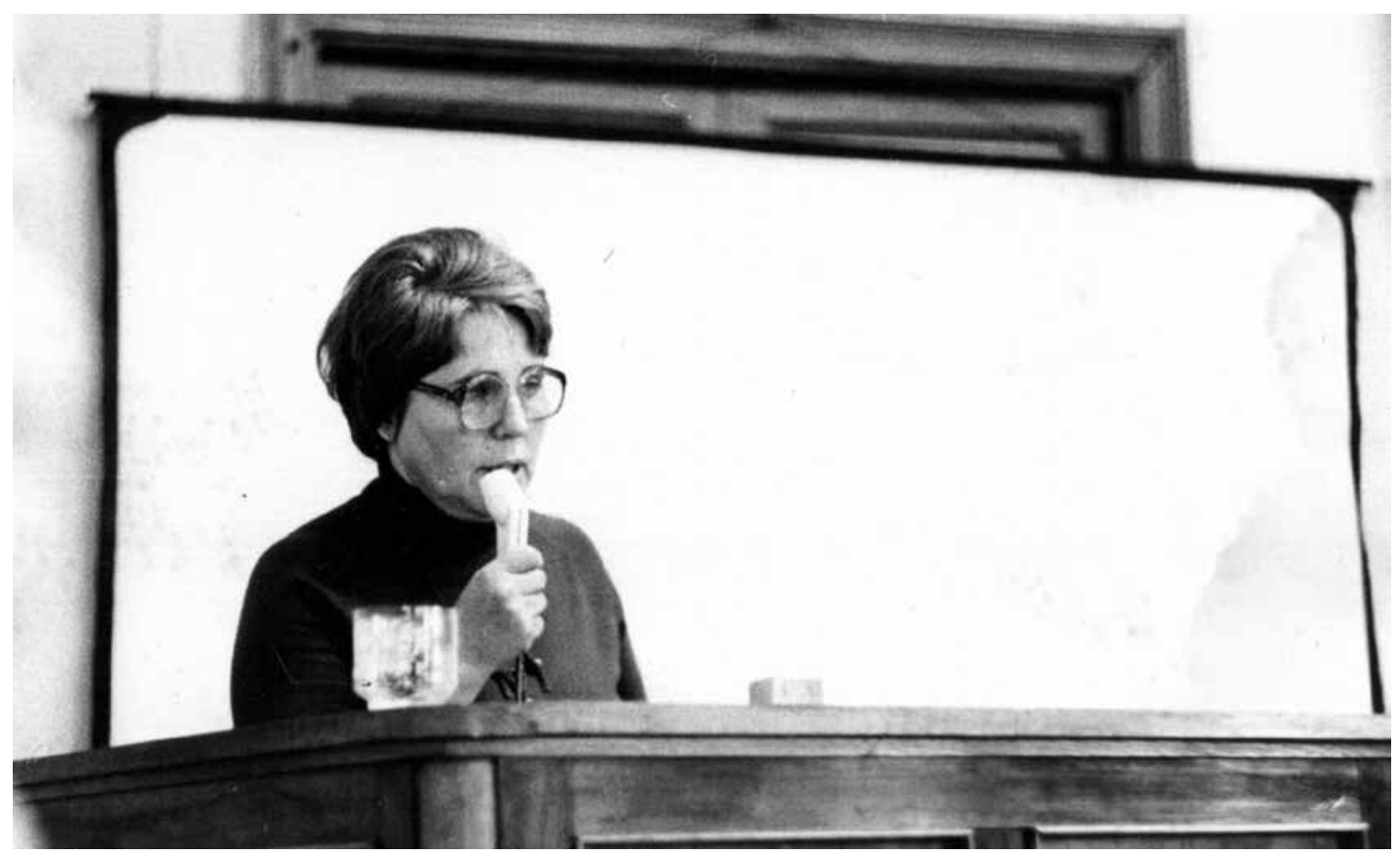

Фото 5. 1984 г.: выступление на I Всесоюзной конференции по анатомии растений 
организмов, выступала на конференциях, на которых докладывала о методиках подготовки объектов для изучения методом СЭМ (фото 5).

$$
* * *
$$

Помимо уже упомянутых методических разработок, НСС очень бережно относилась к строгому и четкому пониманию профессиональной терминологии. Словари, энциклопедии и справочные пособия были самыми ходовыми ее настольными книгами. Естественно, что и она сама, в силу своих сил, использовала любую возможность для объяснения тех или иных терминов, значения слов и понятий, смыслового содержания теорий, гипотез и научных направлений.

В Большой Советской Энциклопедии (БСЭ) ботаническая часть (и палеоботаническая в том числе) составлялась под редакцией академика А.Л. Тахтаджяна. Статья «Палеоботаника» написана НСС в соавторстве с С.Г. Жилиным. О статьях в нескольких основополагающих справочных изданиях по Кувшинкоцветным в целом и роде Nelumbo (Лотос) в частности я уже писал выше. В 4-м томе «Жизни растений» НСС написан целый ряд статей по древним растениям - плауновидным, семенным папоротникам и кордаитовым. В самые последние годы НСС активно сотрудничала с составителями словарей геологического профиля. По приглашению М.В. Ошурковой НСС участвовала в написании ряда статей в новом (третьем), переработанном и исправленном, издании «Геологического словаря». По инициативе специалиста-угольщика Горного института В.В. Кирюкова НСС составила богато иллюстрированную статью «Палеоботаника» для «Российской угольной энциклопедии».

$$
* * *
$$

Одним из самых трагических моментов в жизни НСС был несвоевременный, а от того - особенно болезненно воспринятый - уход из жизни Сергея Вик- торовича Мейена. Их отношения были очень добрыми, дружескими, взаимоуважительными и легкими, насколько я могу судить по своим воспоминаниям и по ее последующим рассказам. Несмотря на то что они никогда не осуществляли совместные экспедиции, не работали коллегиально над теми или иными материалами, хотя их области исследования достаточно сильно пересекались, у них всегда было очень много тем для интересных дискуссий и новых идей.

До того момента НСС не писала некрологов или иных персоналий. Первым был некролог в «Ботаническом журнале», посвященный памяти С.В. Мейена. Приблизительно в это же время НСС начинает увлекаться историей палеоботаники и детально разбирает деятельность основных исследователей древних флор России - И.Ф. Шмальгаузена (преимущественно), А.Н. Криштофовича и М.Д. Залесского. Она знакомится с архивами, забытыми коллекциями в провинциальных и петербургских музеях, с письмами и полевыми заметками этих специалистов. В итоге появляется целый ряд статей и сообщений, в которых НСС оценивает вклад этих ученых в дело изучения ископаемых растений нашего Отечества. Именно НCС принадлежала идея создания Криштофовичских чтений, ставших регулярными палеоботаническими совещаниями, проводящимися в лаборатории палеоботаники БИН РАН. На рабочем столе у нее всегда стоял портрет И.Ф. Шмальгаузена.

В XXI в. наступает время постепенного ухода коллег и друзей НСС в иной мир. Это было непростое для HCC время: кончина Франса Стафле (Frans Stafleu, 1921-1997), Ханса-Йоахима Швайцера (Hans-Joachim Schweitzer, 1928-2007), Сергея Глебовича Жилина (1932-2010). Незадолго до своей смерти Х.-Й Швайцер приезжал в Петербург, чтобы, как он выражался, «проститься с моими русскими друзьями и коллегами», что в итоге стало печальной истиной (фото 6).

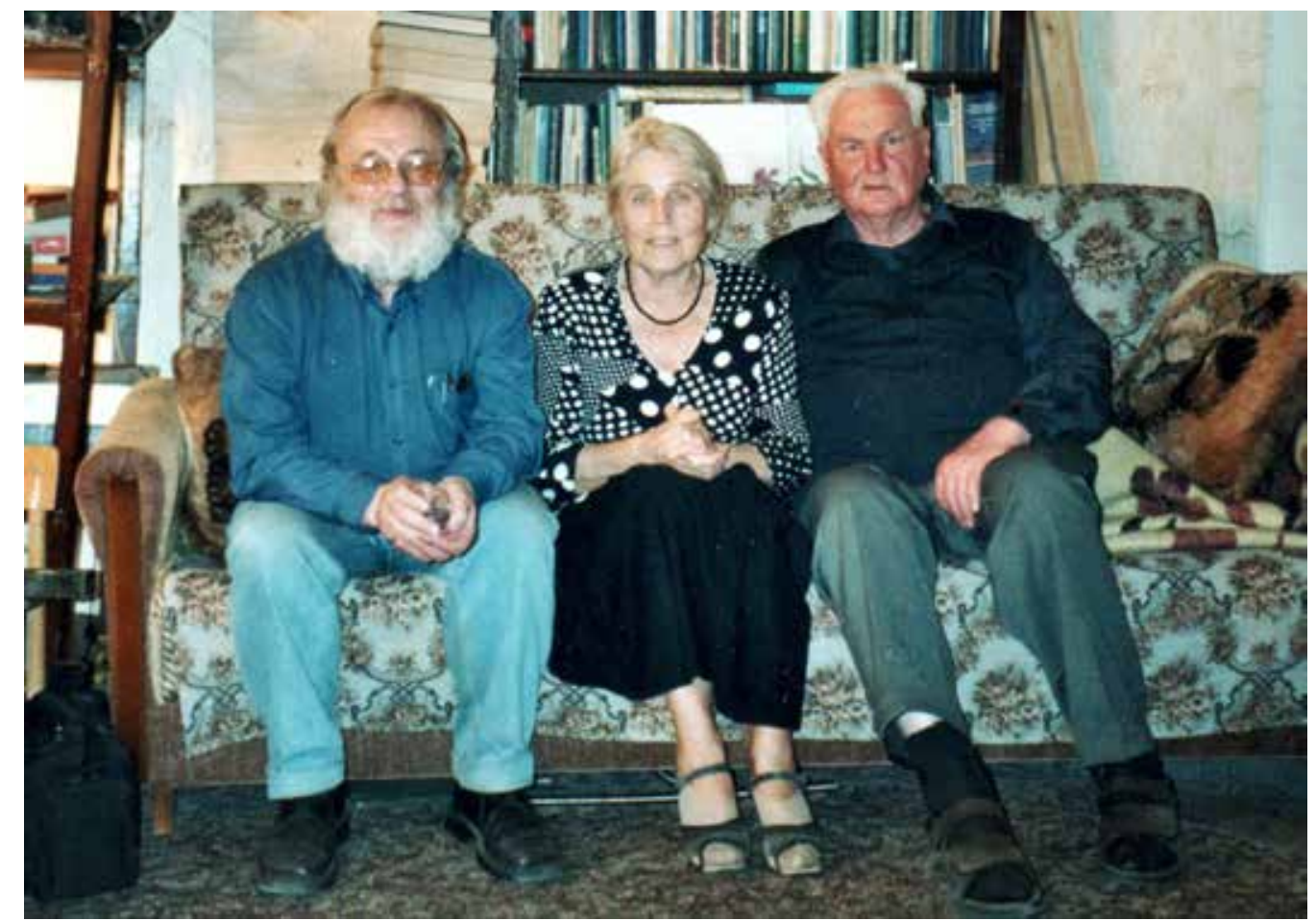

Фото 6. 2005 г. На Большой Посадской. «Прощальная фотография трех палеоботаников». Слева направо: С.Г. Жилин (1932-2010), Н.С. Снигиревская, Ханс-Йоахим Швайцер (Hans-Joachim Schweitzer, 1928-2007). Фото автора 
Безусловно, особое место в жизни НСС занимал ее любимый учитель, ставший близким другом, академик А.Л. Тахтаджян (1910-2009). О нем НСС писала много и щедро, всей душой восхищаясь этим замечательным мыслителем, Ученым с большой буквы. Начиная с публикации перечней его опубликованных работ за определенные периоды и кончая посмертным исследованием его научного наследия [33]. Одно остается мне непонятным: каким образом получилось так, что некролог великого Тахтаджяна не был опубликован в «Ботаническом журнале», главным редактором которого он был не один десяток лет...

Не забывала НСС и о своей любимой преподавательнице университетского периода - Ольге Алексеевне Муравьевой, с которой неоднократно выезжала она на летние ботанические практики, участвовала в экскурсиях, проводимых ею для студентов кафедры ботаники ЛГУ. По иронии судьбы, О.А. Муравьева последние годы жизни провела в том же Доме ветеранов науки в пригороде Ленинграда - городе Пушкине, где спустя многие годы окончила свой жизненный путь и Наталия Сергеевна Снигиревская. В выпуске биологической серии Вестника СПбГУ за 2013 г. есть также статья с воспоминаниями НСС об Ольге Алексеевне Муравьевой.

В 2010-х гг. в Петербурге стал издаваться журнал «Биосфера», главным редактором которого стал известный ботаник, однокурсник и друг НСС Эрик Иосифович Слепян. Он пригласил НСС к сотрудничеству при написании ряда воспоминаний об известном специалисте по анатомии современных растений, профессоре Лесотехнической академии Андрее Алексеевиче Яценко-Хмелевском (1909-1987).

$$
* * *
$$

Кого же можно в итоге назвать учителями и учениками НСС?

С учителями все просто. По сути дела, учитель был один. Зато какой! - Армен Леонович Тахтаджян (фото 7). Я замечал уже выше, что из университетских преподавателей особо ценила и много вспоминала НСС об Ольге Алексеевне Муравьевой, однако как-то между строк осталось и то, что в годы учебы НСС на кафедре большое количество курсов читал ей именно А.Л. Тахтаджян, работавший тогда профессором кафедры ботаники ЛГУ. Совмещавший работу в университете и в Ботаническом институте, Тахтаджян и привлек НСС к поступлению на работу после окончания университета именно в лабораторию палеоботаники БИНа. Там она и проработала всю свою жизнь в течение 60 лет и 11 дней (с 26 ноября 1955 г. по день смерти - 06 декабря 2015 г.).

В одном из писем С.Г. Жилину, датированном 29.11.2005 г., подготавливавшему текст к 95-летнему юбилею А.Л. Тахтаджяна (АЛТ), НСС просила примерно таким образом охарактеризовать их отношения с АЛТ как учителя и ученика и так очертила основной круг своих научных интересов: «Наталия Сергеевна Снигиревская оказалась единственным палеоботаническим учеником Армена Леоновича, воспринявшим его идеи о максимальном насыщении палеоботанических исследований духом эволючиионной морфологии и филогении. Это касается всех ее трудов (около 150), посвященных морфологии, анатомии и систематике вымерших растений палеозоя и мезозоя, в частности археоптерисовым и плауновиднымм, и меловым-третичным лотосовым. Одно из удивительных по сохранности окаменельх растений из класса изоэтопсида, сохранившихся иеликом, она назвала в честь Армена Леоновича - Takhtajania mirabilis Snig. <..> НСС была ученым секретарем ХІІ Международного ботанического конгресса, по приглашению А.Л. Тахтаджяна, который был его президентом. Ее бурная деятельность в должности ученого секретаря в сочетании со свойственной ей ответственностью во многом обусловила успех этого важного мероприятия мирового значения. Научные интересы НСС связаны с несколькими узловыми проблемами палеоботаники: ранняя эволюиия древнейших наземных растений и их взаимоотношения с грибами и водорослями (ордовик, силур и ранний девон), предпосылки появления и развития первых

${ }_{8}^{8}$ В действительности, конечно, Takhtajanodoxa - в тексте допущена ошибка.

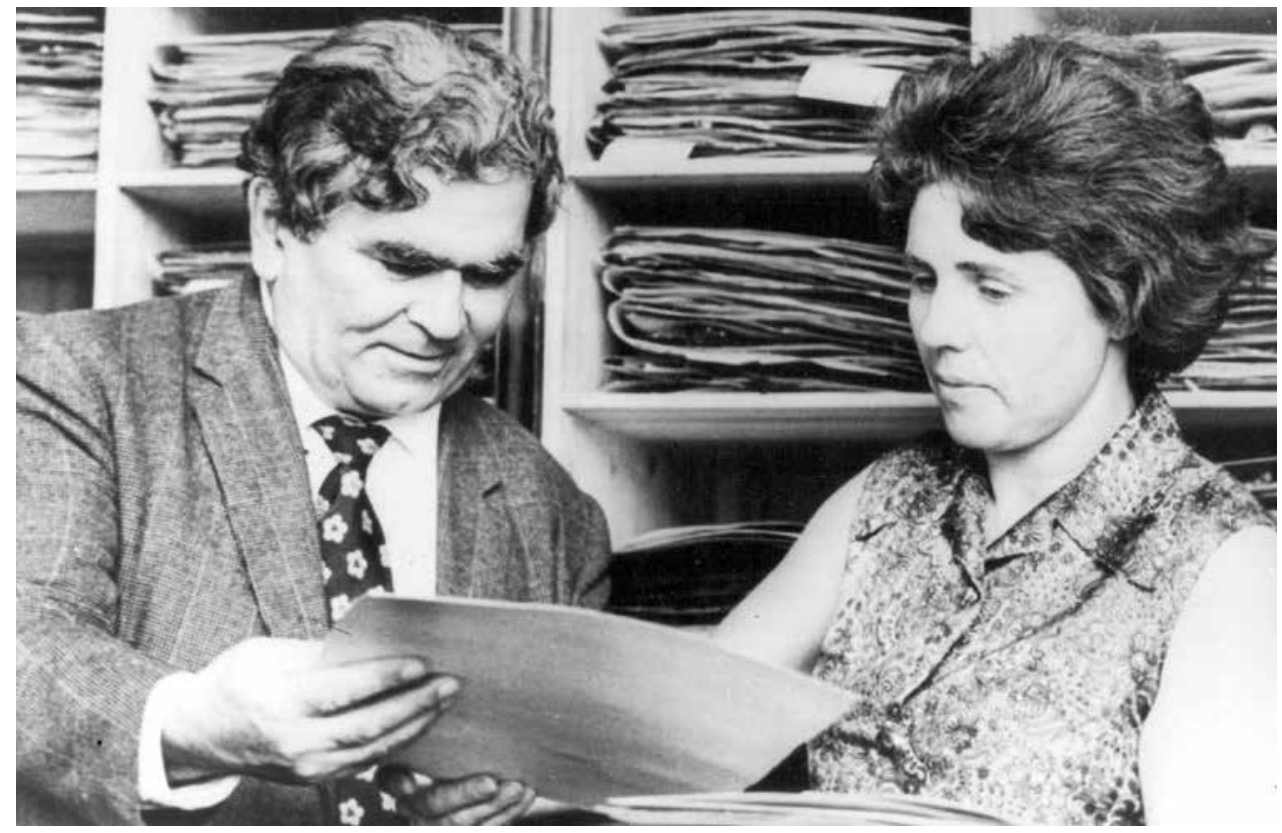

Фото 7. Примерно 1973 г.: А.Л. Тахтаджян и Н.С. Снигиревская, Ботанический институт 
лесных экосистем как важного планетарного явления в истории биосферы (поздний девон); систематический состав, жизненные формы и связанные с ними особенности морфологии и анатомии растений - обитателей влажных тропических лесов, гигантская продуктивность которых была основой для формирования залежей каменного угля (средний карбон), жизненные формы и условия обитания растений раннего мезозоя во флорах высоких иирот обоих полушарий на рубеже перми и триаса; ревизия ископаемых находок лотосовых в мелу и третичном периоде в связи с проблемой достоверности идентификаиии шитовидных листьев вымериих растений».

НСС работала в БИНе в одном кабинете с А.И. Турутановой-Кетовой, в 4-м этаже здания гербария. Ее, наверное, можно считать вторым учителем НСС в палеоботанике. НСС часто отмечала внимательность Антонины Ивановны к ее работам, деловые и дружеские (несмотря на разницу в возрасте) советы. Это объяснялось еще отчасти и тем, что А.И. ТурутановаКетова была хорошо знакома в довоенные годы с ее родителями. Эти рабочие отношения переросли в теплую привязанность и вплоть до кончины Антонины Ивановны (1896-1968 гг.) продолжались, в том числе в обширной переписке, хранящейся в архиве НСС.

Учеников у НСС было также немного. На данный момент я остался единственным, кто продолжает заниматься палеоботаникой. Я был благодатным материалом для того, чтобы научить меня этому. Вопервых, я находился все время рядом с матерью. Во-вторых, и это, наверное, самое главное, мне бесконечно понравилось в первой экспедиции, в которую НСС взяла меня с собой, - в Донбасс, в 1974 г., еще до школы. Именно там я понял, чем именно хочу и буду заниматься в жизни. Еще несколько раз мы ездили с мамой в экспедиции, две из которых были очень длительные и важные для меня в плане осознания своего интереса и о которых я уже упоминал (1976 и 1980 гг.). В дальнейшем мы часто обменивались мнениями, НСС редактировала тексты моих курсовых, дипломной работы, статей, кандидатской диссертации, просила меня подредактировать ее на- метки и черновики статей. Были и наши совместные исследования, как отмечено выше (фото 8).

$$
* * *
$$

Напоследок необходимо сказать о том, что из задуманного стояло в планах НСС и что, по признанию ее самой, не было сделано ранее?

«...меня останавливали Ольга Алексеевна и Армен Леонович от поспешного утверждения новизны наблюдений. Так я не сдала в печать статью о находке сосудов у Nelumbo, ее опубликовали американцы, хотя я их “открыла" в 1952 г. Не опубликовала статью о сосудах у Matonia (1977) и других nanopomников, хотя предложила оригинальную концеепцию эволючии проводящих элементов у высших растений посредством перфорирования боковых стенок и неполного лизиса мембран. Schneider и Carlquist из Ботанического сада в Санта-Барбара опубликовали огромное количество работ на эту тему. Они любезно пересылали до недавнего времени эти работы».

Основные намерения НСС распространялись на издание атласа находок из кимберлитовых трубок севера Европейской России и на внесение ясности в проблему таксономии, номенклатуры и поиска места в системе органического мира грибоподобных организмов группы Prototaxites-Nematophyton.

На момент смерти у НСС были сданы в печать три статьи.

$$
* * *
$$

Предлагаемый вниманию читателя обзор жизни и научного творчества Наталии Сергеевны Снигиревской был написан мной в течение непродолжительного времени.

Наверное, время осознания потери НСС для науки придет позже, тогда, когда мы однажды обнаружим, что в череде публикаций по тем или иным вопросам нет той четкости и упорядоченности мысли, которая всегда отличала ее работы.

Ведь в научном мире память об исследователе сохраняется все то время, пока актуальны его труды самое главное, что остается потомкам.

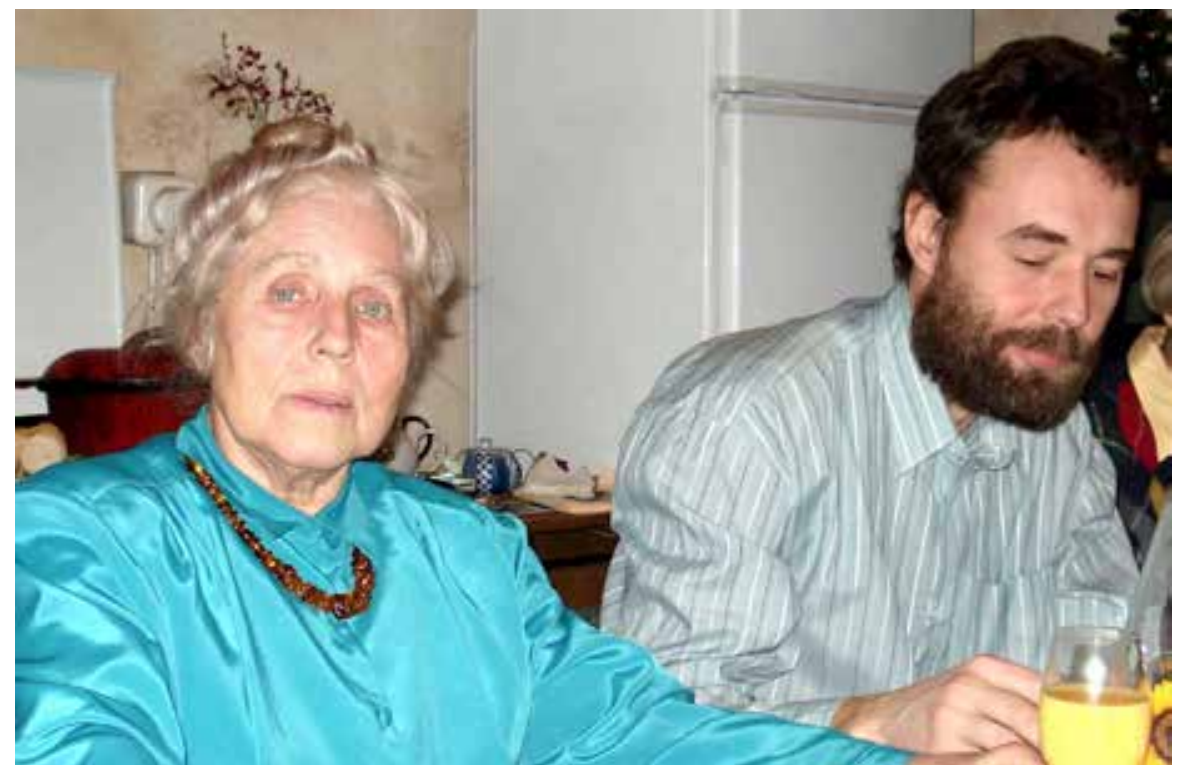

Фото 8. 30.12.2007: Наталия Сергеевна Снигиревская и сын Сергей Михайлович Снигиревский, автор воспоминаний 


\section{Основные публикации Н.С. Снигиревской}

В списке сохранено оригинальное написание всех библиографических данных в соответствии с первоисточником.

\section{Список русскоязычной литературы}

1. Каратыгин ИВ, Снигиревская НС. Палеонтологические свидетельства о происхождении основных таксономических групп грибов. Микология и фитопатология. 2004;38(5):15-31.

2. Каратыгин ИВ, Снигиревская НС. Симбиотрофные грибы в палеоэкосистемах девона. В кн.: Актуальные проблемы биологии и экологии. Сборник научных трудов, посвященный 80-летию Э.И. Слепяна. СПб.; 2011. с. 159-69.

3. Каратыгин ИВ, Снигиревская НС, Викулин СB. Winfrenatia reticulata - древнейший наземный лишайник из нижнего девона; новая находка, новая интерпретация. Палеонт журн. 2009;(1):100-6.

4. Каратыгин ИВ, Снигиревская НС, Викулин CB. Симбиоз гриба и цианобактерий в девоне Микология и фитопатология. 2010;44(1):31-6.

5. Каратыгин ИВ, Снигиревская НС, Демченко КН. Виды рода Glomites как микобионты растений экосистем раннего девона. Палеонт журн. 2006;(5):99-107.

6. Каратыгин ИВ, Снигиревская НС, Демченко КН. Эндомикориза растений в экосистемах раннего девона. Микология и фитопатология. 2006;40(6):494-501.

7. Местонахождения ископаемых растений, нуждающиеся в охране. Труды БИН РАН. Вып 12. Ред. Тахтаджян АЛ. Снигиревская НС, Жилин СГ. СПб.; 1994.

8. Могучева НК, Снигиревская НС. Новый представитель порядка Sphenopsida в раннетриасовой корвунчанской флоре Тунгусского бассейна (Россия). Геология и геофизика. 2012;53(Приложение 18): 87-97.

9. Снигиревская НС. К морфологии и анатомии рода Sphenophyllum (Sphenophyllum plurifoliatum в угольных почках Донецкого бассейна). Палеонт журн. 1959;(2):109-22.

10. Снигиревская НС. К морфологии и систематике рода Botryopteris. Палеонт журн. 1962;(2):122-32.

11. Снигиревская НС. Остатки спороношений Sphenophyllaceae в угольных почках Донбасса. Бот журн. 1962; XLVII(4):546-52.

12. Снигиревская НС. Анатомическое изучение растительных остатков из угольных почек Донбасса. Семейство Lepidodendraceae. В кн.: Палеоботаника. Труды БИН АН СССР. Сер VIII. 1964;(V):5-38

13. Снигиревская НС. Анатомическое исследование остатков некоторых среднекаменноугольных растений из угольных почек Донецкого бассейна. (Дис. ... канд. биол. наук). Л.: БИН АН СССР; 1964.

14. Снигиревская НС. Материалы к морфологии и систематике рода Nelumbo Adans. В кн.: Флора и систематика высших растений. Под ред БК Шишкина. Труды БИН АН СССР. Сер 1. М.-Л.: Наука; 1964;13:104-72.
15. Снигиревская НС. Остатки каламитов и псарониевых папоротников в угольных почках Донбасса. В кн.: Палеоботаника. Труды БИН AH CCCP. Cep VIII. 1967;(VI):5-28.

16. Снігіревська НС. Деякі аспекти палеоботанічного вивчення вугільних стяжінь Донецького басейну. Республ міжвід зб «Викопні фауна і флора України». Вип. 1. Кіїв: Наукова думка; 1973;(1):124-33.

17. Снигиревская НС. Корневище матониевого папоротника (сем. Matoniaceae, пор. Filicales) из юрских отложений Восточной Сибири. Бот журн. 1977;62(6):858-62.

18. Снигиревская НС. Takhtajanodoxa Snig. новое звено в эволюции плауновидных. В кн.: Систематика и эволюция высших растений. Л.: Наука; 1980. с. 45-53.

19. Снигиревская НС. Побег Archaeopteris archetypus с сохранившейся анатомической структурой. Бот журн. 1982;67(9):1237-43.

20. Снигиревская НС. Корневые системы археоптерисовых в верхнем девоне Донбасса. Ежегодник Всесоюзн палеонт общества. 1984;XXVII:28-41.

21. Снигиревская НС. Методы палеоботанического исследования окаменелых торфов в среднекарбоновых углях Донецкого бассейна. Бот журн. 1984;69(12):1691-8.

22. Снигиревская НС. О так называемой «лепидодендропсисовой флоре» Донбасса и ее геологическом возрасте. Бот журн. 1987;72(12):1561-71.

23. Снигиревская НС. Поздний девон - время появления лесов как природного явления. В кн.: Становление и эволюция континентальных биот. Труды XXXI сессии Всесоюзн палеонт общества. Л.: Наука, 1988. с. 115-24.

24. Снигиревская НС. Еще раз о статусе рода Pleuromeia Corda. В кн.: Вопросы палеофлористики и стратиграфии. Л.: Наука, 1989. с. 74-88.

25. Снигиревская НC. Physostoma elegans (Lyginopteridales) в угольных почках Донецкого бассейна. Бот журн. 1989;74(10):1442-50.

26. Снигиревская НС. Листовой диморфизм и природа семядолей у Nelumbo (Nelumbonaceaе). Бот журн. 1992;77(12):1-6.

27. Снигиревская НС. О принадлежности Orestovia voronejiensis T. Istchenko et A. Istchenko (средний девон, Воронежская антеклиза) к высшим растениям. Палеонт журн. 1993;(4):133-7.

28. Снигиревская НС. Археоптерисовые и их значение в эволюции растительного покрова суши. Бот журн. 1995;80(1):70-6.

29. Снигиревская НС. О проблематичности находок высших растений в ордовике Казахстана и некоторые аспекты происхождения наземной флоры. Топорковские чтения. Рудный, 1997;(3):184-90.

30. Снигиревская НС. Новые отделы Archaeopteridophyta и Archaeospermatophyta и их отношения с некоторыми другими группами девонских растений. Бот журн. 2000;85(7): 134-44.

31. Снигиревская НС. К номенклатуре ископаемых растений. Бот журн. 2008;93(2):231-44. 
32. Снигиревская НС. Статус плауновидных и некоторые проблемы девонского углеобразования. Бот журн. 2010;95(6):758-76.

33. Снигиревская НС. Армен Леонович Тахтаджян, кратко о нем, об эволюции его научных интересов и трактовке тектологии как универсальной эволюционной науки. Takhtajania. 2011;(1):18-24.

34. Снигиревская НС. Значение палеоботанического анализа детрита в жерлах вулканических трубок (Архангельская область, Россия). Бот журн. 2012;97(11):1459-71.

35. Снигиревская НС. Вулканическая природа Тунгусского взрыва 1908 года и его значение для понимания истории растительных ландшафтов Средней Сибири России. Бот журн. 2014;99(7):749-55.

36. Снигиревская НС, Богданова ЛА. Находка устьиц и ксилемы у растений рода Barsassia (Asteroxylaceae, Lycopodiophyta) из среднего девона Кузнецкого бассейна и некоторые аспекты стоматографического исследования древних растений. Бот журн. 1992;77(1):58-66.

37. Снигиревская НС, Громыко ДВ, Могучева НК. Остатки стволов Septomedullocaulon putoranicum gen. et sp. nov. (? Podocarpaceae s.1.) из вулканогенных отложений нижнего триаса Тунгусского бассейна (Средняя Сибирь). Бот журн. 1999;84(11):125-37.

38. Снигиревская НС, Могучева НК. Находка окаменелого корня Chromorhiza gen. n. (Pinopsida incertae sedis) в триасовых отложениях плато Путорана (Тунгусская синеклиза) и ее научное значение. Приложение к журналу «Геология и геофизика». Новости палеонтологии и стратиграфии. 2010;51(14):37-50.

39. Снигиревская НС, Попов ЛЕ, Здебска Д. Новые находки остатков древнейших высших растений в среднем ордовике Южного Казахстана. Бот журн. 1992;77(4):1-9.

40. Снигиревская НС, Сребродольская ИН. Первая находка окаменелых стеблей Pleuromeia (Lycopodiophyta) c сохранившимся анатомическим строением. Бот журн. 1986;71(4):411-5.

41. Снигиревская НС, Фефилова ЛА. Новое местонахождение окаменелых древесин $\mathrm{Xe}$ noxylon (Pinopsida incertae sedis) в мезозойских отложениях Земли Франца Иосифа, датированных миоспорами, и его значение. В кн.: Материалы по фанерозою полярных областей и центральной части Срединно-Атлантического хребта. Фауна, флора и биостратиграфия. Труды НИИГА-ВНИИОкеангеология. Т. 211. СПб., 2007. с. 111-8.

42. Снигиревская НС, Фисуненко ОП, Иконникова ИК и др. О первой находке Litostrobus в угольных почках карбона Донецкого бассейна. Геол журн. 1977;37(3):140-7.

43. Снигиревский СМ, Снигиревская НС. Некоторые новые данные о девонских спорах in situ и комментарии к номенклатуре дисперсных спор. В кн.: Прищепа ОМ, Субетто ДА, Дзюба ОФ, отв. ред. Палинология: стратиграфия и геоэкология. Сборник научных трудов XII Всероссийской палинологической кон- ференции (29.09-4.10.2008 г., СПб). Т. І. СПб.:

ВНИГРИ, 2008. с. 108-15.

44. Снигиревский СМ, Снигиревская НС. Ископаемые растения в окрестностях СанктПетербурга. В кн.: Снигиревский СМ, Синай МЮ, ред. Многогранная геология. Вып. 2. СПб.: ВНИИОкеангеология, 2008. с. 121-39.

45. Тахтаджян АЛ, Снигиревская НС. Отчет о подготовке и проведении XII Международного ботанического конгресса (Ленинград, 3-10 июля, 1975 г.). 11 ноября 1975. с. 1-94.

46. Фефилова ЛА, Могучева НК, Снигиревская НС. Первая находка шишки Aetophyllum (Coniferales) с пыльцой Alisporites и Triadispora in situ в вулканогенных отложениях Тунгусского бассейна (Средняя Сибирь, плато Путорана). Материалы по фанерозою полярных областей и центральной части Срединно-Атлантического хребта. Фауна, флора и биостратиграфия. Труды НИИГА-ВНИИОкеангеология. Т. 211. СПб., 2007. с. 119-30.

\section{Общий список литературы/Reference List}

1. Karatygin IV, Snigirevskaya NS. [Palaeontologic evidences on an origin of the basic taxonomic groups of Fungi. Mikologiya i Fitopatologiya]. 2004;38(5):15-31. (In Russ.)

2. Karatygin IV, Snigirevskaya NS. [Symbiotrophic fungi in the Devonian palaeoecosystems]. In: Aktualnye Problemy Biologii i Ekologii. Sbornik Nauchnykh Trudov Posviaschennyi 80-letiyu EI Slepyana. Saint-Petersburg, 2011. p. 15969. (In Russ.)

3. Karatygin IV, Snigirevskaya NS, Vikulin SV. [The most ancient terrestrial lichen Winfrenatia reticulata: a new find and new interpretation]. Paleontologicheskiy Zhurnal. 2009;(1):100-6. (In Russ.)

4. Karatygin IV, Snigirevskaya NS, Vikulin $\mathrm{SV}$. [Symbiosis between fungus and cyanobacteria in the Devonian]. Mikologiya i Fitopatologiya. 2010;44(1):31-6. (In Russ.)

5. Karatygin IV, Snigirevskaya NS, Demchenko KN. [Species of the genus Glomites as plant mycobionts in Early Devonian ecosystems]. Paleontologicheskiy Zhurnal. 2006;(5):99-107. (In Russ.)

6. Karatygin IV, Snigirevskaya NS, Demchenko KN. [Endomicorrhizae of plants from Early Devonian ecosystems]. Mikologiya i Fitopatologija. 2006;40(6):494-501. (In Russ.)

7. [Fossil plant localities to be protected]. In: Takhtajan AL, Snigirevskaya NS, Zhilin SG, eds. Proc Komarov Botanical Institute. Issue 12. Saint Petersburg; 1994. (In Russ.)

8. Mogutcheva NK, Snigirevskaya NS. [New taxa of Sphenopsida in the Lower Triassic Korvunchana flora from the Tunguska basin (Russia)]. Geologiya i Geofizika. 2012;53(Suppl 18): 87-97. (In Russ.)

9. Snigirevskaya NS. [On the morphology and the anatomy of the genus Sphenophyllum]. Paleontologicheskiy Zhurnal. 1959;(2):109-22. (In Russ.)

10. Snigirevskaya NS. [On the morphology and taxonomy of the genus Botryopteris]. Paleontologicheskiy Zhurnal. 1962;(2):122-32. (In Russ.)

11. Snighirevskaya NS. [The remnants of Sphenophyllaceae with traces of sporulation found in 
the coal balls from the Donetz Coal Basin]. Botanicheskiy Zhurnal. 1962;XLVII(4):546-52. (In Russ.)

12. Snigirevskaya $\underline{\mathbf{S}}$. An anatomical study of the plant remains from the Donets coal-balls. I Lepidodendraceae. In: Palaeobotanica. Acta Inst Bot nom VI Komarovii Acad Sci URSS. Ser. VIII. Fasc. V. 1964, p. 5-38. (In Russ.)

13. Snigirevskaya NS. [Anatomical study of some Middle Carboniferous plant fossils from the coal-balls of Donets Basin (dissertation)]. Leningrad: Komarov Bot Inst.; 1964. (In Russ.)

14. Snigirevskaya NS. [Contributions to the morphology and taxonomy of the Genus Nelumbo Adans]. In: Flora et systematica plantae vasculares. A BK Schischkin redacta. Ser. 1. Fasc. 13. 1964c, p. 104-72. (In Russ.)

15. Snigirevskaya NS. [The remains of Calamites and psaroniaceous ferns in coal-balls of the Donets basin]. In: Palaeobotanica. Acta Inst Bot nom VI Komarovii Acad Sci URSS. Ser. VIII Fasc. VI. 1967, p. 5-28. (In Russ.)

16. Snigirevskaya NS. Donets coal balls and some aspects of their paleobotanical study. In: Respublikans'kyi Mezhvidomstvennyj Zbirnyk "Vikopny Fauna i Flora Ukrainy". Issue 1. Kiev: Naukova Dumka; 1973, p. 124-33. (In Russ.)

17. Snigirevskaya NS. [Rhizome of the matoniaceous fern (Family Matoniaceae, Order Filicales) from the Jurassic deposits of East Siberia. Botanicheskiy Zhurnal]. 1977;62(6):858-62. (In Russ.)

18. Snigirevskaya NS. Takhtajanodoxa Snig. new link in the evolution of Lycopods. In: Systematika i Evolutzia Vysshikh Rasteniy. Leningrad, Nauka: 1980, p. 45-53. (In Russ.)

19. Snigirevskaya NS. The shoot of Archaeopteris archetypus with preserved anatomical structure. Botanicheskiy Zhurnal. 1982;67(9):1237-43. (In Russ.)

20. Snigirevskaya NS. [The root systems of Archaeopterids in the Upper Devonian of Donets basin]. Yezhegodnik Vsesoyuznogo Paleontologicheskogo Obschestva. 1984;XXVII:28-41. (In Russ.)

21. Snigirevskaya NS. [A technique for palaeobotanical studies of petrified peats in the Middle Carboniferous coals from Donets basin]. Botanicheskij Zhurnal. 1984;69(12):1691-8. (In Russ.)

22. Snigirevskaya NS. [On the so-called "Lepidodendropsis-flora" of the Donets basin and its geological age]. Botanicheskij Zhurnal. 1987;72(12):1561-71. (In Russ.)

23. Snigirevskaya NS. [Late Devonian - the time of the appearance of forests as a natural henomenon]. In: Stanovleniye i Evolutsiya Kontinentalnykh Biot Trudy XXXI Sessii Vsesoyuznogo Paleontologicheskogo Obshtchestva. Leningrad: Nauka; 1988, p. 115-24. (In Russ.)

24. Snigirevskaya NS. [Once again about the status of genus Pleuromeia Corda]. In: Voprosy Paleofloristiki i Stratigrafiji. Leningrad: Nauka; 1989. p. 74-88. (In Russ.)

25. Snigirevskaya NS. Physostoma elegans (Lyginopteridales) in coal balls of Donets basin. Botanicheskiy Zhurnal. 1989;74(10):1442-50. (In Russ.)

26. Snigirevskaya NS. [Leaf dimorphism and the cotyledon nature of Nelumbo (Nelumbonaceae)] Botanicheskiy Zhurnal. 1992;77(12):1-6. (In Russ.)
27. Snigirevskaya NS. [New data supporting the classification of Orestovia voronejiensis T. Istchenko et A. Istchenko (Middle Devonian, Voronezh anteclise) with higher plants]. Paleontologicheskiy Zhurnal. 1993;(4):133-7. (In Russ.)

28. Snigirevskaya NS. [Archaeopterids and their role in the land plant cover evolution]. Botanicheskiy Zhurnal. 1995;80(1):70-6. (In Russ.)

29. Snigirevskaya NS. [On the doubtful character of the higher plant finds in the Ordovician of the Kazakhstan and some aspects of the land flora evolution]. In: Toporkovskiye Chteniya Vypusk 3. Rudnyi; 1997, p. 184-90. (In Russ.)

30. Snigirevskaya NS. [Archaeopteridophyta and Archaeospermatophyta divisio novum and their relations to some other groups of Devonian plants]. Botanicheskiy Zhurnal. 2000;85(7):13444. (In Russ.)

31. Snigirevskaya NS. [Towards the nomenclature of fossil plants]. Botanicheskiy Zhurnal. 2008;93(2):231-44. (In Russ.)

32. Snigirevskaya NS. [The status of Lycopsids and some problems of Devonian coal formation]. Botanicheskiy Zhurnal. 2010;95(6):758-76. (In Russ.)

33. Snigirevskaya NS. [Armen Leonovich Takhtajan: briefly about him, the evolution of his scientific interests and interpretation of tectology as a universal evolutionary science]. Takhtajania. 2011;(1):18-24. (In Russ.)

34. Snigirevskaya NS. [The importance of the palaeobotanical analysis of detritus inside volcanic pipe craters (the Arkhangelsk region, Russia)]. Botanicheskiy Zhurnal. 2012;97(11):1459-71. (In Russ.)

35. Snigirevskaya NS. The volcanic origin of the Tunguska explosion and its importance for understanding the history of plant landscapes in the Middle Siberia (Russia). Botanicheskiy Zhurnal. 2014;99(7):749-55. (In Russ.)

36. Snigirevskaya NS, Bogdanova LA. [Finding of stomata and xylem in plants of the genus Barsassia (Asteroxylaceae, Lycopodiophyta) from the Middle Devonian of the Kuznets basin and some questions of the stomatographic study of ancient plants]. Botanicheskiy Zhurnal. 1992;77(1):58-66. (In Russ.)

37. Snigirevskaya NS, Gromyko DV, Mogutcheva NK. [Trunk remains of Septomedullocaulon putoranicum gen. et sp. nov. (? Podocarpaceae s.1.) from volcanogenic deposits of Tunguska basin (the Middle Siberia, Lower Triassic)]. Botanicheskiy Zhurnal. 1999;84(11):125-37. (In Russ.)

38. Snigirevskaya NS, Mogutcheva NK. [Petrified fossil root Chromorhiza gen. n. (Pinopsida incertae sedis) in the Triassic of Plateau Putorano (Tunguska syneclise) and its significance]. Geologiya i Geofizika. 2010;51(14 Suppl):37-50. (In Russ.)

39. Snigirevskaya NS, Popov LE, Zdebska D. [New findings of the oldest higher plants remains in the Middle Ordovician of the South Kazakhstan]. Botanicheskiy Zhurnal. 1992;77(4):1-9. (In Russ.)

40. Snigirevskaya NS, Srebrodolskaya IN. [The first finding of petrified stems of Pleuromeia (Lyco- 
podiophyta) with the preserved anatomical structure]. Botanicheskiy Zhurnal. 1986;71(4):411-5. (In Russ.)

41. Snigirevskaya NS, Fefilova LA. [New locality of petrified stems of Xenoxylon (Pinopsida incertae sedis) in the Mesozoic sediments of Franz-Joseph Land, dated by miospores, and its significance]. Trudy Nauchno-Issledovatelskogo Instituta Geologii Arktiki VNIIOkeangeologiya. 2007;211:111-8. (In Russ.)

42. Snigirevskaja NS, Fisunenko OP, Ikonnikova IK et al. [On the first finding of Litostrobus in the Carboniferons coal balls of the Donets basin]. Geologichnyj Zhurnal. 1977;37(3):140-7. (In Russ.)

43. Snigirevsky SM, Snigirevskaya NS. [Some new data on Devonian in situ spores and comments to the nomenclature of sporae dispersae]. In: Palynology Stratigraphy and Geoecology. Collection of the Scientific Works of XII All-Russian Palynological Conference (29 September - 4 October 2008, Saint Petersburg). Vol. I. Saint Petersburg: VNIGRI, 2008. p. 108-15. (In Russ.)

44. Snigirevsky SM, Snigirevskaya NS. [Fossil plants around Saint Petersburg]. In: Snigirevsky SM, Sinaj MYu, eds. Mnogogrannaya Geologiya. Saint Petersburg: VNIIOkeangeologija. 2008. p. 121-39. (In Russ.)

45. Takhtajan AL, Snigirevskaya NS. [Report on the Preparation and Conduct of the XII ${ }^{\text {th }}$ International Botanical Congress (Leningrad, 3-10 July, 1975)]. Leningrad; 1975. p. 1-94. (In Russ.)

46. Fefilova LA, Mogutcheva NK, Snigirevskaya NS. [The first finding of the Aetophyllum-cone (Coniferales) with pollen Alisporites and Triadispora in situ in volcanogenous sediments of Tunguska basin (Middle Siberia, Putorana plateau)]. Trudy Nauchno-Issledovatelskogo Instituta Geologii Arktiki VNIIOkeangeologija. 2007;211:119-30. (In Russ.)
47. Lemoigne $\mathrm{Y}$, Iurina $\mathrm{A}$, Snigirevskaya $\mathrm{N}$. Revision du genre Callixylon Zalessky, 1911 ( $A r$ chaeopteris) du Devonien. Palaeontographica. Abt. B. 1983;186(4/6):81-120.

48. Snigirevskaya NS. Studies of coal balls of the Donets basin. Rev Palaebot Palynol. 1972;14:197204.

49. Snigirevskaya NS. A unique mode of the natural propagation of Ginkgo biloba L. - the key to the problem of its survival. Acta palaeobot. 1994;34(2):215-23.

50. Snigirevskaya NS, Gromyko DV. Scanning electron microscopy as a key to the recognition of the cross-field types in fossil coniferous wood from the Arctic. Acta Palaeobot. 2000;40(1):39-42.

51. Snigirevskaya N, Lemoigne I. Nouveau gisement dévonien à Callixylon dans le centre de la Sibérie. Conséquences pour la phytogéographie, la climatologie et les relations continentales au Dévonien supérieur. C R Acad Sci Paris. Ser. II. 1990;311:1557-62.

52. Snigirevskaya NS, Nadler YuS. Habit and relationships of Orestovia (Middle Devonian). Palaeontographica. Abt. B. 1994;233(1-6):11-8.

53. Snigirevskaya NS, Snigirevsky SM. New locality of Callixylon (Archaeopteridaceae) in the Upper Devonian of Andoma mountain (Vologda Region, north-west Russia) and its importance for the reconstruction of archaeopterids distribution. Acta palaeobot. 2001;41(2):97-105.

54. Zodrow E, Snigirevskaya NS, Palmer CA. Paleoenvironments, and carbonate processes in plant-tissue preservation of calcite coal balls: limnic Donets basin Russia and Ukraine (Middle Carboniferous). In: Hills LV, Henderson CM, Bamber EV, eds. Carboniferous and Permian of the world. Can Soc Petrol Geol Mem. 2002;19:393-411. 